Check for updates

Cite this: RSC Adv., 2017, 7, 34922

Received 22nd April 2017

Accepted 4th July 2017

DOI: 10.1039/c7ra04525e

rsc.li/rsc-advances

\section{Platinum-copper doped poly(sulfonyldiphenol/ cyclophosphazene/benzidine)-graphene oxide composite as an electrode material for single stack direct alcohol alkaline fuel cells}

\begin{abstract}
Prasanna Dakshinamoorthy and Selvaraj Vaithilingam (DD *
The present work has attempted to prepare platinum-copper ( $\mathrm{Pt}-\mathrm{Cu}$ ) and platinum (Pt) nanoparticle-deposited poly(sulfonyldiphenol/cyclophosphazene/benzidine)-graphene oxide catalysts for the electrochemical oxidation of alcohols and single stack direct alkaline alcohol fuel cells. Electrochemical performance of methanol and ethylene glycol is measured using Pt-Cu/poly(SDP/CP/BZ)-GO and Pt/poly(SDP/CP/BZ)-GO catalysts as the working electrode in $\mathrm{KOH}$ solution using cyclic voltammetry analysis. Platinum-copper and platinum nanoparticles embedded with the poly(SDP/CP/BZ)-GO composite show enhanced electrooxidation current, lower onset potential and good $\mathrm{CO}$ tolerance compared to that of $\mathrm{Pt} / \mathrm{GO}$ and $\mathrm{Pt} /$ poly(SDP/CP/BZ) catalysts. Further, the Pt-Cu/poly(SDP/CP/BZ)-GO catalyst exhibits enhanced catalytic activity with respect to lower onset potential and higher oxidation current than that of the Pt/poly(SDP/CP/ BZ) catalyst. Hence, single stack direct alcohol alkaline fuel cells are constructed using the Pt-Cu/poly(SDP/ CP/BZ) -GO catalyst as an electrode material. The optimum power densities of 112.24 and $140.67 \mathrm{~mW} \mathrm{~cm}^{-2}$ are observed for methanol and ethylene glycol in single direct alkaline alcohol fuel cells.
\end{abstract}

\section{Introduction}

The direct alkaline alcohol fuel cell (DAAFC) is a potent and attractive electrochemical device, which generates electricity from liquid alcohol fuel due to its promising energy conversion, lower corrosion, high energy density, high energy conversion efficiency, low operating temperature and environmental friendliness. The significant advantages of direct alcohol fuel cells (DAFC) such as, easy to handle, store, transport and refuel, make the DAFC an attractive substitute to batteries and combustion engines. Recent reports state that the alcohol oxidation in alkaline medium is kinetically faster than in acidic media. ${ }^{1-5}$ Moreover, the cost of proton conducting polymer membranes like Nafion used in direct acid alcohol fuel cells is higher than that of anion exchange membranes used in direct alkaline alcohol fuel cell applications. Further, the poisoning issue of the electrode material and alcohol crossover limits the performance of proton exchange membranes. In addition, the direction of the electro-osmotic drag is from the anode to the cathode in acid medium, which reduces the cell performance. The reaction kinetics and catalytic activities of the anodic oxidation of fuel and the cathodic reduction of $\mathrm{O}_{2}$ in alkaline media are significantly higher than those in acidic media.

Nanotech Research Lab, Department of Chemistry, University College of Engineering Villupuram, (A Constituent College of Anna University, Chennai), Kakuppam, Villupuram-605 103, Tamilnadu, India. E-mail: vaithilingamselvaraj@gmail.com; vselva@aucev.edu.in; rajselva_77@yahoo.co.in; Fax:+91-4146-224500
The development of novel electrode materials operated at low temperature is essential for the diverse applications. A potential advantage of the direct alkaline alcohol fuel cell is that the alcohol in alkaline medium is less structure sensitive of the catalyst than in acid media. Hence, the structure of the catalyst will not be changed during the electrooxidation of alcohol in alkaline medium.

Graphene oxide (GO) is a good catalyst support due to its high electron in-plane transport rate, simple preparation method and low cost carbon in comparison with CNT. Graphene oxide based nanocomposites are paying more attention as a new material because of their extraordinary physical and chemical properties for various applications. Graphene oxide based nanocomposites were applied for the fabrication of electronic devices, batteries, super capacitor, solar cells, fuel cells and electrocatalytic applications. ${ }^{6-9}$ Further, the recent reports state that the GO supported platinum nanoparticles composite exhibits superior electrocatalytic activities and high poison tolerance for alcohol oxidation when compared to that of other carbon supported platinum nanoparticles. ${ }^{10-13}$

Furthermore, to enhance the stability, activity and dispersibility of metal nanoparticles, the GO are coupled with conductive polymers like poly(aniline), poly(pyrrole), poly(thiophene), etc., to a form conductive polymer/GO composites. ${ }^{\mathbf{1 4 - 1 6}}$ Such, composite materials show strong interaction with metal nanoparticles, which exhibits better electrocatalytic activity and stability. Hence, a new type of conductive polymer is attempted to coat over the graphene oxide surface to get covalent bonded conductive polymer-graphene oxide composite along with $\pi-\pi$ stack interaction. The 
designing of new composite materials with a hexachlorocyclotriphosphazene group as a linker for multiple monomers as well as with graphene oxide have attracted more attention because of their special desired coupling to get a new type of linkage between graphene oxide and monomers during the polymerization process. The composite covalent bond along with noncovalent bond formation such as $\pi-\pi$ stack interaction, the van der Waals force of attraction and hydrogen bonding are expected to show good thermal stability, catalytic properties, electrical conductivity, and stable under aggressive condition. ${ }^{17}$

With this view in mind, the present work is projected to prepare poly(sulfonyldiphenol/cyclophosphazene/benzidine) polymer-graphene oxide composite as a supporting material for platinum $(\mathrm{Pt})$ and platinum-copper $(\mathrm{Pt}-\mathrm{Cu})$ nanoparticles. $\mathrm{Pt}-\mathrm{Cu} /$ poly(SDP/CP/BZ)-GO catalyst is fabricated and subjected to electrooxidation of alcohol oxidation in alkaline medium. Further, the electrooxidation of alcohol oxidation on $\mathrm{Pt} / \mathrm{pol}$ $\mathrm{y}(\mathrm{SDP} / \mathrm{CP} / \mathrm{BZ})-\mathrm{GO}, \mathrm{Pt} / \mathrm{poly}(\mathrm{SDP} / \mathrm{CP} / \mathrm{BZ})$ and Pt/GO were also investigated in order to confirm the efficiency of poly(SDP/CP/ $\mathrm{BZ}$ )-GO composite as supporting material. The electrochemical performance investigation concludes that the poly(SDP/CP/BZ)GO composite is a good supporting material for the deposition of metal nanoparticles with uniform distribution and shows improved electrocatalytic oxidation of methanol and ethylene glycol for fuel cell applications. Further, the best performed catalyst $\mathrm{Pt}-\mathrm{Cu} / \mathrm{poly}(\mathrm{SDP} / \mathrm{CP} / \mathrm{BZ})-\mathrm{GO}$ was used to fabricate single stack direct alcohol alkaline fuel cell and their performance were checked under different experimental condition to optimize the single stack test fuel cell.

\section{Experimental methods}

\subsection{Materials}

Hexachlorocyclotriphosphazene (HCCP) and benzidine (BZ) were purchased from Sigma Aldrich, India. Reagent grade 4,4'sulfonyldiphenol, potassium permanganate $\left(\mathrm{KMnO}_{4}\right)$, concentrated sulfuric acid $\left(\mathrm{H}_{2} \mathrm{SO}_{4}\right)$, sodium nitrate $\left(\mathrm{NaNO}_{3}\right)$, formaldehyde (HCHO), graphite powder, ethylene glycol, methanol, ethanol, hexachloroplatinic acid hexahydrate $\left(\mathrm{H}_{2} \mathrm{PtCl}_{6} \cdot 6 \mathrm{H}_{2} \mathrm{O}\right)$ and copper chloride $\left(\mathrm{CuCl}_{2}\right)$ were purchased from SRL, India.

\subsection{Preparation of graphene oxide}

Graphene oxide was prepared from the natural flake graphite according to the modified Hummers method. ${ }^{18,19}$ In this method, $2.0 \mathrm{~g}$ of graphite powder and $4.0 \mathrm{~g}$ of $\mathrm{NaNO}_{3}$ were added to $80 \mathrm{~mL}$ of cold $\left(0{ }^{\circ} \mathrm{C}\right)$ concentrated $\mathrm{H}_{2} \mathrm{SO}_{4}$ in an ice bath. Then, $\mathrm{KMnO}_{4}(8.0 \mathrm{~g})$ was added gradually under stirring and care was taken to maintain the reaction temperature below $10{ }^{\circ} \mathrm{C}$. The reaction mixture was continuously stirred for another $4 \mathrm{~h}$ during which the reaction temperature is maintained below $10{ }^{\circ} \mathrm{C}$. Next, the reaction mixture was stirred at $35{ }^{\circ} \mathrm{C}$ for further $4 \mathrm{~h}$ and then diluted with $200 \mathrm{~mL}$ of deionized (DI) water. The addition of water in concentrated sulfuric acid medium releases a large amount of heat and thus the addition of water was performed under an ice bath environment to keep the temperature below $100{ }^{\circ} \mathrm{C}$. After adding DI water, the mixture was stirred for another $1 \mathrm{~h}$. Finally, $15 \mathrm{~mL}$ of $30 \% \mathrm{H}_{2} \mathrm{O}_{2}$ solution was added to the above reaction mixture in order to terminate the reaction. The solid product was separated by centrifugation process and washed three times with $5 \% \mathrm{HCl}$ solution. The resulting solid was re-dispersed in DI water and dialyzed for three days to remove the residual salts and acids. The solid suspension was filtered and dried in a vacuum oven at $45{ }^{\circ} \mathrm{C}$ for $48 \mathrm{~h}$ to obtain graphite oxide for further use.

\subsection{Preparation of poly(sulfonyldiphenol/ cyclophosphazene/benzidine)-graphene oxide (poly(SDP/CP/ BZ)-GO) composite}

For the preparation of poly(SDP/CP/BZ)-GO composite, $10 \mathrm{mg}$ of graphene oxide was dispersed in $80 \mathrm{~mL}$ of DMSO solution. $20 \mathrm{mg}$ of hexachlorocyclotriphosphazene (CP), $29 \mathrm{mg}$ of benzidine, $29 \mathrm{mg}$ of 4,4'-sulfonyldiphenol (SDP) and $4 \mathrm{~mL}$ of triethylamine (TEA) were added to the above reaction mixture. The polycondensation reaction was carried out in an ultrasonic bath $(100 \mathrm{~W}, 40 \mathrm{kHz})$ at room temperature for $12 \mathrm{~h}$. After completion of the reaction, the poly $(\mathrm{SDP} / \mathrm{CP} / \mathrm{BZ})-\mathrm{GO}$ composite was filtered and its impurities were removed by washing repeatedly with distilled water and then dried at $60{ }^{\circ} \mathrm{C}$ in an oven for $24 \mathrm{~h}$.

\subsection{Synthesis of platinum and platinum-copper nanoparticles deposited poly(SDP/CP/BZ)-GO composite}

For the Pt/poly(SDP/CP/BZ)-GO catalyst preparation, $30 \mathrm{mg}$ of poly(SDP/CP/BZ)-GO composite was suspended in $5 \mathrm{~mL}$ distilled water and stirred under ultrasonic treatment for $20 \mathrm{~min} .54 \mathrm{mg}$ of $\mathrm{H}_{2} \mathrm{PtCl}_{6} \cdot 6 \mathrm{H}_{2} \mathrm{O}$ dissolved in $20 \mathrm{~mL}$ of distilled water is added to the above reaction mixture and the $\mathrm{pH}$ of the reaction mixture was adjusted to 11 with $2.5 \mathrm{M} \mathrm{NaOH} .1 .0 \mathrm{~mL}$ of formaldehyde (37\%) was added to the above solution at $85^{\circ} \mathrm{C}$ in order to initiate the reduction process to deposit the platinum on poly(SDP/CP/BZ)-GO composite. The reaction was continued for another $5 \mathrm{~h}$ in order to complete the reduction of platinum salts to Pt nanoparticles. The resultant solid was filtered, washed with distilled water and then dried at $60{ }^{\circ} \mathrm{C}$ for 8 hours. The Pt-Cu nanoparticles were deposited on $60 \mathrm{mg}$ of poly(SDP/CP/BZ)-GO composite by following similar experimental procedure with $54 \mathrm{mg}$ of $\mathrm{H}_{2} \mathrm{PtCl}_{6} \cdot 6 \mathrm{H}_{2} \mathrm{O}, 14 \mathrm{mg}$ of $\mathrm{CuCl}_{2}$ and $2 \mathrm{~mL}$ of $\mathrm{HCHO}$ to get $\mathrm{Pt}-\mathrm{Cu} /$ poly(SDP/CP/BZ)-GO catalyst. For comparative studies, the platinum nanoparticles were also deposited on graphene oxide and poly(SDP/CP/BZ) by utilizing similar experimental conditions.

\subsection{Physicochemical and electrochemical characterizations}

The physicochemical characterizations were done by using FTIR, HRTEM and EDX analysis. The prepared graphene oxide and poly $(\mathrm{SDP} / \mathrm{CP} / \mathrm{BZ})$ materials have been examined by Fourier transform infrared (FTIR, Thermo Nicolet Model: 6700) spectroscopy. The Raman spectra of graphite powder and graphene oxide are recorded using $1064 \mathrm{~nm}$ line of Nd:YAG laser as the excitation wavelength in the region $500-2500 \mathrm{~cm}^{-1}$ on a Thermo Electron corporation model Nexus 670 spectrophotometer. Xray diffraction patterns were measured at $25{ }^{\circ} \mathrm{C}$ temperature by examining the diffraction angle $2 \theta$ from 0 to $10^{\circ}$ as the standard on a Rich Seifert (Model 3000) X-ray powder 
diffractometer. The surface morphology, size of platinum and platinum-copper nanoparticles deposited on poly(SDP/CP/BZ)GO composite are analyzed by high resolution transmission electron microscope (HR-TEM, JEOL) with an accelerating voltage of $120 \mathrm{kV}$. Energy dispersive X-ray analysis (EDX, INCA200) substantiates the presence of platinum and platinum-copper nanoparticles on poly(SDP/CP/BZ)-GO composite.

\subsection{Electrochemical characterizations}

Multichannel electrochemical workstation with inbuilt FRA system (Biologic SAS, Model VSP2) was used for electrochemical characterizations with a standard three-electrode glass cell equipped with novel modified graphite electrodes as working, saturated calomel electrode as reference and a platinum wire as counter electrodes. Further, the electrocatalytic activity of alcohol (methanol and ethylene glycol) oxidation has been investigated in $0.5 \mathrm{M} \mathrm{KOH}$ and $0.5 \mathrm{M}$ alcohol solution with a potential range of -1.0 to $0.3 \mathrm{~V}$ at a scan rate of 20,50 and $100 \mathrm{mV} \mathrm{s}^{-1}$. Chronoamperometric analysis was also done in $0.5 \mathrm{M} \mathrm{KOH}$ and $0.5 \mathrm{M}$ alcohol solution at its maximum peak current potential. The CO stripping testing was carried out by holding the working electrode in the carbon monoxide saturated $\mathrm{KOH}$ solution $(0.5 \mathrm{M})$ for $500 \mathrm{~s}$, and then the working electrode is placed in the nitrogen gas purged $0.5 \mathrm{M} \mathrm{KOH}$ solution to record the CO stripping profiles. The intermediate products formed upon electrooxidation of ethylene glycol were determined by using high-performance liquid chromatography (Dionex system P680 HPLC). It works with an isocratic elution and mainly includes an autosampler (ASI 100 Automated Sample Injector), a sample loop $(20 \mu \mathrm{L})$, and an ion-exclusion column (Aminex HPX-87H), which are operated at room temperature. The analytes were separated with diluted $\mathrm{KOH}$ (3.3 $\mathrm{mmol} \mathrm{L}^{-1}$, Merck 96\%) used as a eluent with $0.6 \mathrm{~mL} \mathrm{~min}^{-1}$ run rate. The chromatograph was equipped with an UV-Vis detector $(\lambda=210 \mathrm{~nm})$ followed by a refractive index detector (IOTA2).

\subsection{Procedure for the construction of single stack test fuel cell}

Direct alcohol alkaline fuel cell was prepared by utilizing anion exchange membrane (AEM) (thickness: $28 \mu \mathrm{m}$, IEC: $1.9 \mathrm{mmol}$ $\mathrm{g}^{-1}$, Tokuyama Co.). $5 \mathrm{mg}$ of electrode catalyst was dispersed in a mixture $1: 1(\mathrm{v} / \mathrm{v})$ ratio of 2-ethoxyethanol and anion exchange ionomer (Tokuyama Co.), and then stirred to form homogeneous slurry. Catalyst $(2.5 \mathrm{mg})$ was coated on carbon paper by brush coating method. The sandwiched layer like structure of the anode and cathode on both the sides of anion exchange membrane was obtained by hot-pressing $\left(120^{\circ} \mathrm{C}, 2 \mathrm{MPa}\right.$ for 10 min) method. The prepared sandwich type of anode and cathode layers were placed between two copper meshes as current collector. The alcohols (methanol and ethylene glycol) were purged in the inlet at anode side. The fuel diffused into the anode catalyst layer from the tank through the anode current collectors, while oxygen transferred into the cathode catalyst layer from the surrounding air through the cathode current collectors by natural convection. The $I-V$ curve measurements were performed with a galvanostat (Hokuto Denko, HA-501G). Each measurement was started after the fuel was poured in the cell for $30 \mathrm{~min}$. The cell voltage was recorded after setting up the current for $3 \mathrm{~min}$ to stabilize the voltage. The single direct alcohol alkaline fuel cell operated at different concentration and temperature for the optimization process.

\section{Results and discussions}

\subsection{FT-IR and FT-Raman spectroscopy}

Graphite and graphene oxide materials were characterized by FTIR and Raman analyses to confirm their respective structures. Fig. 1(a) displays the FTIR spectra of graphite and graphene oxide materials. The peaks appeared at 3405 and $1403 \mathrm{~cm}^{-1}$ are corresponding to the $\mathrm{O}-\mathrm{H}$ stretching and bending vibration present in graphene oxide. The $\mathrm{C}=\mathrm{O}$ stretching vibration of - $\mathrm{COOH}$ groups present in the graphene oxide sheets is observed at $1727 \mathrm{~cm}^{-1}$ (ref. 20) and the $\mathrm{C}=\mathrm{O}$ stretching of hydrogen bonded carboxylic group has appeared at $1624 \mathrm{~cm}^{-1}$. The characteristic peaks corresponding to the functional groups of graphene oxide were absent in the case of graphite powder, which infers the conversion of graphite powder into graphene oxide material.

Raman spectroscopy is an effective, non-destructive and well know tool to find the structural characteristics and quality of graphene based materials. So, the Raman spectra were carried out for graphite and graphene oxide materials (Fig. 1(b)). The Raman spectrum of graphite powder shows a single sharp G band at $1630 \mathrm{~cm}^{-1}$, which is corresponding to the vibration of $\mathrm{sp}^{2}$ carbon. The graphene oxide shows two peaks at 1645 and $1380 \mathrm{~cm}^{-1}$ are known as the $\mathrm{G}$ band (growth band) and D band (disordered band), respectively. The broad and intense D-band appeared at $1380 \mathrm{~cm}^{-1}$ is corresponding to $\mathrm{sp}^{3}$ hybridized carbon atoms, which are confirming the graphene oxide conversion from graphite material. Further, the shift in the $\mathrm{G}$ band (growth band) is observed for graphene oxide, which might be due to the reduction in size and in-plane $\mathrm{sp}^{2}$ domains due to extensive oxidation. This indicates the defects within the graphitic sheets and edges. ${ }^{21,22}$ The $\mathrm{G}$ band arises due to the hexagonal lattice vibrations of GO, which is the characteristic of graphene "honeycomb" structure of GO.

Fig. 2 shows the FTIR spectra of graphene oxide and pol$\mathrm{y}(\mathrm{SDP} / \mathrm{CP} / \mathrm{BZ})-\mathrm{GO}$ composite. The FTIR spectrum of poly(SDP/ $\mathrm{CP} / \mathrm{BZ}$ )-GO has the characteristic bands at 3309 and $840 \mathrm{~cm}^{-1}$ for $-\mathrm{N}-\mathrm{H}$ stretching and wagging vibrations, respectively. The peak corresponding to $\mathrm{C}=\mathrm{O}$ stretching of carboxylic group is observed at $1768 \mathrm{~cm}^{-1}$.

The shift in the peak position from 1727 to $1768 \mathrm{~cm}^{-1}$ for $\mathrm{C}=\mathrm{O}$ stretching of carboxylic group as in the case of poly(SDP/ $\mathrm{CP} / \mathrm{BZ}$ )-GO composite when compared to GO material indicates the chemical interaction between the polymer and GO material. The stretching and bending vibrations of $\mathrm{O}-\mathrm{H}$ in GO spectrum at 3405 and $1403 \mathrm{~cm}^{-1}$ were disappeared as in the case of pol$\mathrm{y}(\mathrm{SDP} / \mathrm{CP} / \mathrm{BZ})-\mathrm{GO}$ composite, which confirms the chemical bonding between the polymer and GO material. The $\mathrm{O}=\mathrm{S}=\mathrm{O}$ stretching vibration was appeared at $1380 \mathrm{~cm}^{-1}$ indicates the presence of sulfonyldiphenol on poly(SDP/CP/BZ)-GO material. 

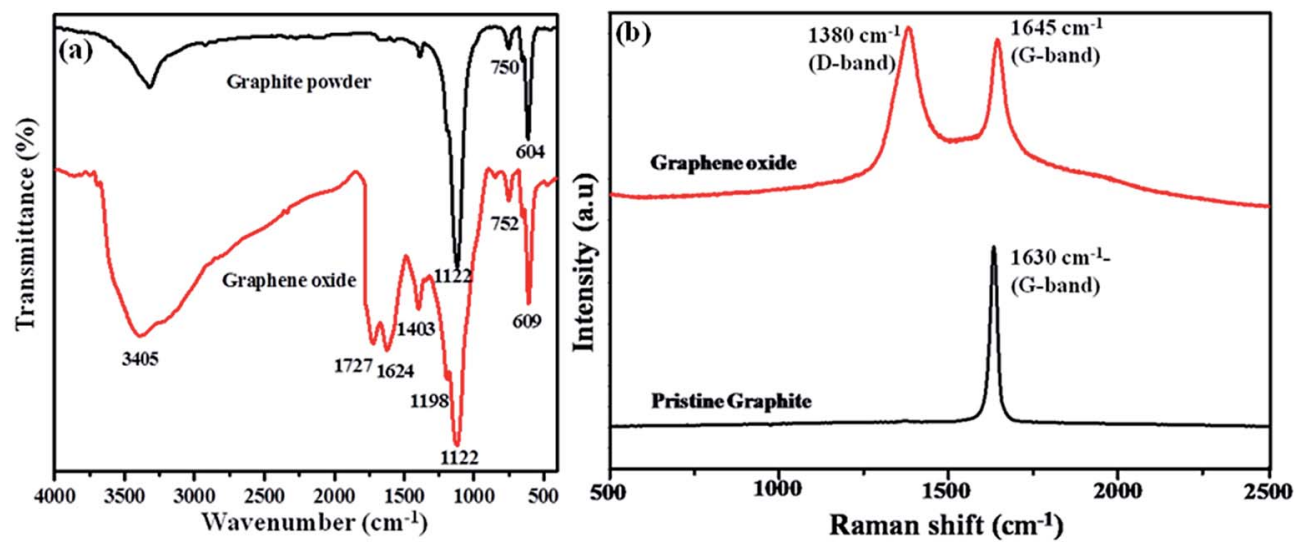

Fig. 1 (a) FT-IR and (b) FT-Raman spectra of graphite and graphene oxide materials.

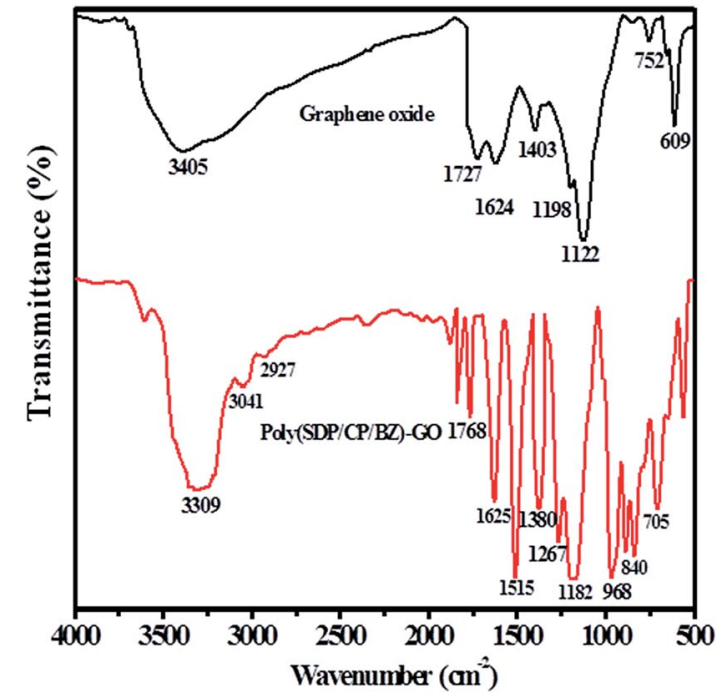

Fig. 2 FTIR spectrum of graphene oxide and poly(SDP/CP/BZ)-GO composite.

The characteristic peaks observed at 1268 and $968 \mathrm{~cm}^{-1}$ confirm the presence of $\mathrm{P}-\mathrm{O}-\mathrm{C}$ and $\mathrm{P}-\mathrm{N}-\mathrm{C}$ bond in poly(SDP/ $\mathrm{CP} / \mathrm{BZ}$ )-GO material. Further, the aromatic $-\mathrm{C}-\mathrm{H}$ stretching vibration was observed at $3043 \mathrm{~cm}^{-1}$. Thus, the above discussions confirm that the poly(SDP/CP/BZ)-GO is composed of $4,4^{\prime}$ sulfonyldiphenol (SDP), cyclophosphazene (CP), benzidine and GO materials.

\subsection{High resolution transmission electron microscope and energy dispersive X-ray analysis}

The size distribution, shape and surface morphology of the platinum and platinum-copper nanoparticles present on poly(SDP/ CP/BZ)-GO composite was analyzed by HRTEM measurements. Fig. 3(a and b) shows the TEM photos of Pt/poly(SDP/CP/BZ)-GO and $\mathrm{Pt}-\mathrm{Cu} / \mathrm{poly}(\mathrm{SDP} / \mathrm{CP} / \mathrm{BZ})-\mathrm{GO}$ catalysts. The TEM photos (Fig. 3(a and b)) confirm the uniform deposited of platinum and platinum-copper nanoparticles on the surface of the poly $(\mathrm{SDP} / \mathrm{CP} /$ BZ)-GO. The uniform size and homogeneous distribution of metal nanoparticles on poly(SDP/CP/BZ)-GO composite surface might be due to the presence of multiple functional groups such as $-\mathrm{NH}$, $\mathrm{P}=\mathrm{N}-,-\mathrm{C}=\mathrm{O}$ and $\mathrm{S}=\mathrm{O}$ on poly(SDP/CP/BZ)-GO surface, which are acting as a good anchoring site for metal nanoparticles deposition. In addition to that the poly(SDP/CP/BZ)-GO composite will favor good dispersion of $\mathrm{Pt}$ and $\mathrm{Pt}-\mathrm{Cu}$ nanoparticles with an average particle size of 2.8 and $2.2 \mathrm{~nm}$, respectively.

Further, the EDX spectra of Pt/poly(SDP/CP/BZ)-GO and Pt$\mathrm{Cu} /$ poly(SDP/CP/BZ)-GO catalysts confirm the presence of platinum and platinum-copper nanoparticles on the poly(SDP/ CP/BZ)-GO composite (Fig. 3(c and d) and Table 1). The EDX spectra result also confirms that the composition of $\mathrm{Pt}$ and $\mathrm{Cu}$ are nearly $1: 1$ ratio, which is good agreement with the calculated theoretical values.

\subsection{Cyclic voltammetry analysis}

3.3.1. Electrooxidation of alcohols. The electrocatalytic performance of $\mathrm{Pt} /$ poly(SDP/CP/BZ)-GO and $\mathrm{Pt}-\mathrm{Cu} /$ poly(SDP/ $\mathrm{CP} / \mathrm{BZ}$ )-GO catalysts were checked by cyclic voltammetry (CV) studies in alkaline solutions of methanol and ethylene glycol fuels. Fig. 4 shows cyclic voltammograms of $\mathrm{Pt} / \mathrm{poly}(\mathrm{SDP} / \mathrm{CP} /$ $\mathrm{BZ})-\mathrm{GO}$ and $\mathrm{Pt}-\mathrm{Cu} /$ poly(SDP/CP/BZ)-GO electrodes in $0.5 \mathrm{M}$ $\mathrm{KOH}, 0.5 \mathrm{M} \mathrm{KOH}+0.5 \mathrm{M}$ methanol and $0.5 \mathrm{M} \mathrm{KOH}+0.5 \mathrm{M}$ ethylene glycol at scan rate $50 \mathrm{mV} \mathrm{s}^{-1}$. The oxidation current of methanol and ethylene glycol on Pt/poly(SDP/CP/BZ)-GO and $\mathrm{Pt}-\mathrm{Cu} /$ poly(SDP/CP/BZ)-GO catalysts are tabulated in the Table 2. $\mathrm{Pt}-\mathrm{Cu} /$ poly(SDP/CP/BZ)-GO catalyst shows higher oxidation current for methanol and ethylene glycol when compared to that of $\mathrm{Pt} / \mathrm{poly}(\mathrm{SDP} / \mathrm{CP} / \mathrm{BZ})-\mathrm{GO}$ catalyst. For comparative studies, electrooxidation of methanol were also carried out on the $\mathrm{Pt} / \mathrm{GO}$ and $\mathrm{Pt} / \mathrm{poly}(\mathrm{SDP} / \mathrm{CP} / \mathrm{BZ})$ catalysts and their results conclude that the $\mathrm{Pt} / \mathrm{poly}(\mathrm{SDP} / \mathrm{CP} / \mathrm{BZ})-\mathrm{GO}$ catalyst shows enhanced catalytic activity current for methanol compared to $\mathrm{Pt} / \mathrm{GO}$ and Pt/poly(SDP/CP/BZ) catalysts.

The enhanced electrocatalytic performance of $\mathrm{Pt} / \mathrm{poly}(\mathrm{SDP} /$ $\mathrm{CP} / \mathrm{BZ}$ )-GO catalyst might be due to (i) the introduction of poly(SDP/CP/BZ) polymer on graphene oxide with multi functional groups such as $-\mathrm{OH},-\mathrm{NH}$ and $\mathrm{S}=\mathrm{O}$ groups, which are helping to get the uniform size distribution of nanoparticles 

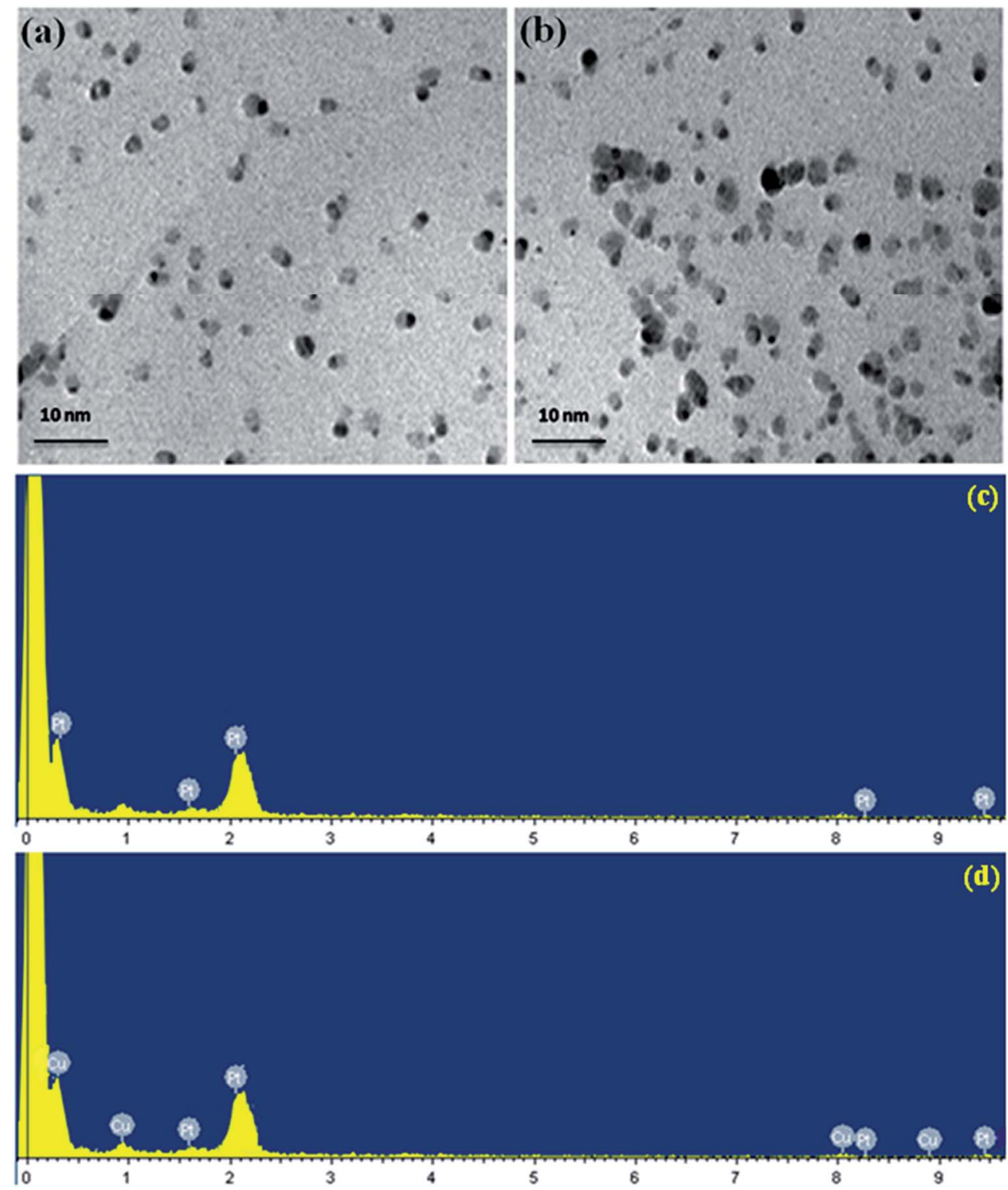

Fig. 3 HRTEM pictures of (a) Pt (b) Pt-Cu decorated poly(SDP/CP/BZ)-GO and EDX spectra of (c) Pt (d) Pt-Cu decorated poly(SDP/CP/BZ)-GO catalysts.

with reduced aggregations. Their results generate more active sites for adsorption of alcohols (methanol and ethylene glycol) towards electrochemical oxidation, (ii) poly(SDP/CP/BZ) present in $\mathrm{Pt} / \mathrm{poly}(\mathrm{SDP} / \mathrm{CP} / \mathrm{BZ})-\mathrm{GO}$ can prevent the agglomeration of graphene oxide as well as metal nanoparticles, which bring homogeneous coexistence between the nanoparticles and (iii) the electron transfer efficiency through an interfacial

Table 1 Atomic and weight composition of Pt/poly(SDP/CP/BZ)-GO and Pt-Cu/poly(SDP/CP/BZ)-GO catalysts

\begin{tabular}{lll}
\hline Catalysts & Weight composition\% & Atomic composition\% \\
\hline $\mathrm{Pt}_{100}$ & 100 & 100 \\
$\mathrm{Pt}_{50}-\mathrm{Cu}_{50}$ & $51: 49$ & $50: 50$
\end{tabular}

interaction between metal nanoparticles and poly(SDP/CP/BZ)GO composite.

Further, to reduce the cost of the electrode material without compromising the catalytic activity, the non precious metal was doped with platinum metal. This is not only reducing the cost, but also enhances the catalytic activity. For this case, the copper $(\mathrm{Cu})$ was doped along with platinum on poly(SDP/CP/BZ)-GO composite as supporting through in situ reduction method to form Pt-Cu/poly(SDP/CP/BZ)-GO bimetallic system. The resultant $\mathrm{Pt}-\mathrm{Cu} / \mathrm{poly}(\mathrm{SDP} / \mathrm{CP} / \mathrm{BZ})-\mathrm{GO}$ catalyst was subjected to methanol and ethylene glycol oxidation in alkaline medium. The cyclic voltammograms of Pt-Cu/poly(SDP/CP/BZ)-GO catalyst for methanol and ethylene glycol in $0.5 \mathrm{M} \mathrm{KOH}$ solution at a scan rate of $50 \mathrm{mV} \mathrm{s}^{-1}$ were shown in Fig. 4 . 

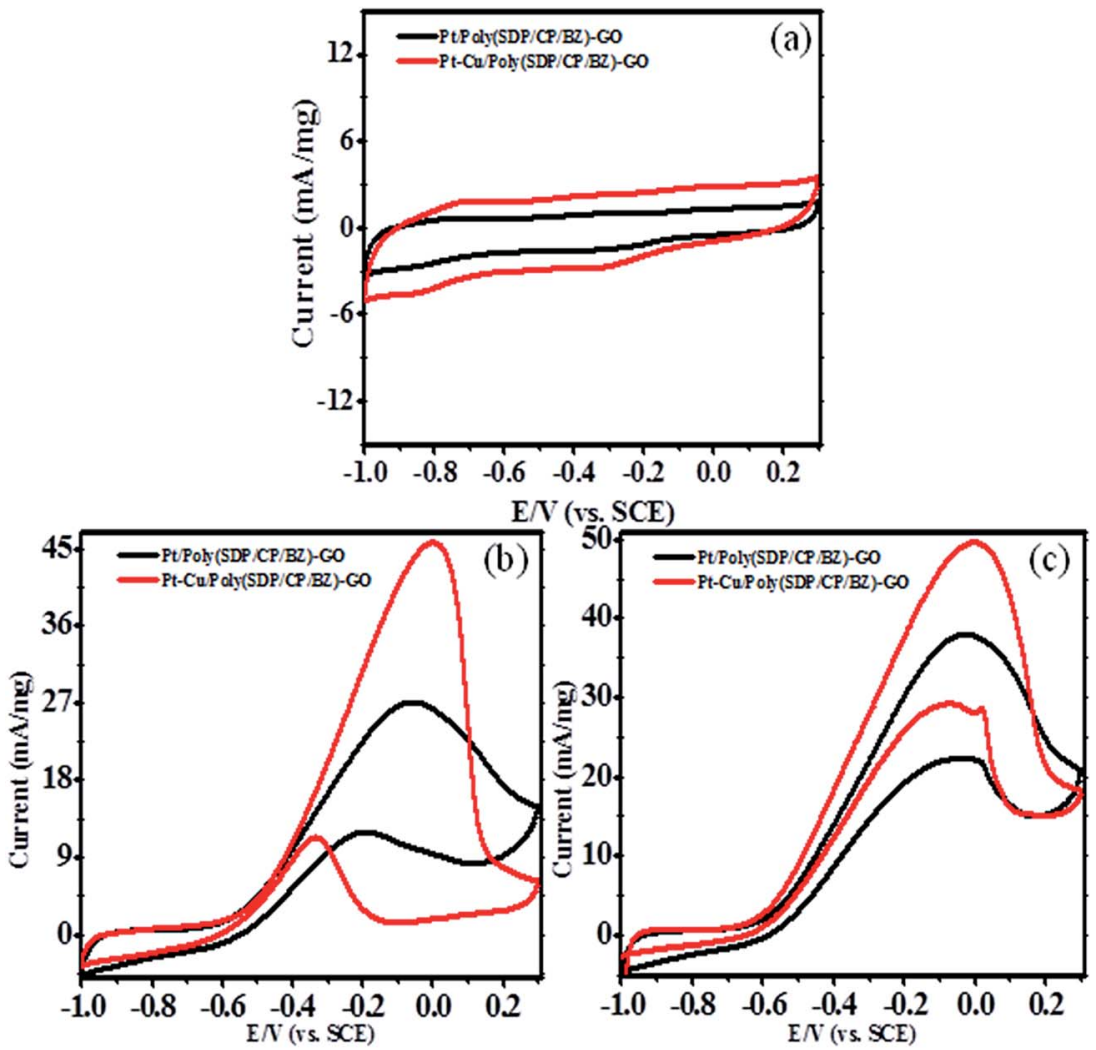

Fig. 4 Cyclic voltammograms of Pt and Pt-Cu decorated poly(SDP/CP/BZ)-GO electrode in (a) $0.5 \mathrm{M} \mathrm{KOH}$ (b) $0.5 \mathrm{M} \mathrm{KOH}+0.5 \mathrm{M} \mathrm{methanol} \mathrm{and}$ (c) $0.5 \mathrm{M} \mathrm{KOH}+0.5 \mathrm{M}$ ethylene glycol at scan rate $50 \mathrm{mV} \mathrm{s}^{-1}$.

$\mathrm{Pt}-\mathrm{Cu} /$ poly(SDP/CP/BZ)-GO catalyst shows significantly enhance oxidation current of 45.03 and $49.60 \mathrm{~mA} \mathrm{mg}^{-1}$ for methanol and ethylene glycol oxidation, respectively. From the results (Table 2), it was concluded that $\mathrm{Pt}-\mathrm{Cu} / \mathrm{poly}(\mathrm{SDP} / \mathrm{CP} / \mathrm{BZ})-\mathrm{GO}$ catalyst shows considerably greater oxidation peak current than that of Pt/poly(SDP/CP/BZ)-GO catalyst. The enhanced electrocatalytic activity of $\mathrm{Pt}-\mathrm{Cu} /$ poly(SDP/CP/BZ)-GO may be stimulated due to the changes in the geometric and electronic structure of the Pt nanoparticles with the introduction of second metal like copper, chemical interaction between poly(SDP/CP/BZ) and GO present in poly(SDP/CP/BZ)-GO composite and the synergy effect between the metal nanoparticles and poly(SDP/CP/BZ)-GO composite. In addition to that the copper is more electronegative metal than the platinum, so the interaction between platinum and copper present in the $\mathrm{Pt}-\mathrm{Cu} / \mathrm{poly}(\mathrm{SDP} / \mathrm{CP} / \mathrm{BZ})-\mathrm{GO}$ catalyst may change the

Table 2 Oxidation peak currents of methanol and ethylene glycol on $\mathrm{Pt} /$ poly(SDP/CP/BZ)-GO and Pt-Cu/poly(SDP/CP/BZ)-GO catalysts

\begin{tabular}{lll}
\hline & \multicolumn{2}{c}{ Current $\left(\mathrm{mA} \mathrm{mg}^{-1}\right)$} \\
\cline { 2 - 3 } Catalyst & Methanol & Ethylene glycol \\
\hline Pt/GO & 10.50 & 12.83 \\
Pt/poly(SDP/CP/BZ) & 13.21 & 16.49 \\
Pt/poly(SDP/CP/BZ)-GO & 27.24 & 37.99 \\
Pt-Cu/poly(SDP/CP/BZ)-GO & 45.03 & 49.60
\end{tabular}

distribution of electrons in platinum. This effect is making more capable and possibilities for the adsorption of alcohols such as methanol and ethylene glycol on platinum surfaces. Hence, this phenomenon stimulates to increases the adsorption and the electrooxidation rate of methanol and ethylene glycol, etc.

Further, the enhanced electrooxidation of methanol and ethylene glycol can be explained based on their intermediate formation during the oxidation process as given below.

(i) Methanol. The formation of $\mathrm{HCOO}^{-}$ion and 'CO' species formed during the electrooxidation of methanol,

$$
\begin{gathered}
\mathrm{Pt}+\mathrm{CH}_{3} \mathrm{OH}+4 \mathrm{OH}^{-} \rightarrow \mathrm{Pt}-\mathrm{CO}+4 \mathrm{H}_{2} \mathrm{O}+4 \mathrm{e}^{-} \\
\mathrm{Pt}-\mathrm{CO}+\mathrm{Pt}-\mathrm{OH} \rightarrow \mathrm{CO}_{2}+2 \mathrm{Pt}+\mathrm{H}^{+} \\
\mathrm{Pt}+\mathrm{CH}_{3} \mathrm{OH}+5 \mathrm{OH}^{-} \rightarrow \mathrm{Pt}-\mathrm{OOCH}+4 \mathrm{H}_{2} \mathrm{O}+4 \mathrm{e}^{-} \\
\mathrm{Pt}-\mathrm{OOCH}+\mathrm{Pt}-\mathrm{OH} \rightarrow 2 \mathrm{Pt}+\mathrm{CO}_{2}+\mathrm{H}_{2} \mathrm{O}+2 \mathrm{e}^{-}
\end{gathered}
$$

Hence, still there is possible to 'CO' poisonous species which is unavoidable in the presence of platinum metal, though enhanced oxidation current is observed as in the case of $\mathrm{Pt} /$ poly(SDP/CP/BZ)-GO, when compared to $\mathrm{Pt} / \mathrm{GO}$ and $\mathrm{Pt} /$ poly(SDP/CP/BZ) catalysts.

According to the above proposed mechanism, major intermediate formed is $\mathrm{HCOO}^{-}$and 'CO' poison during electrooxidation of methanol. Copper in $\mathrm{Pt}-\mathrm{Cu} / \mathrm{poly}(\mathrm{SDP} / \mathrm{CP} / \mathrm{BZ})-\mathrm{GO}$ catalyst will assist the catalyst to undergo through the ' $\mathrm{HCOO}^{-}$, 
ion formation and it also assist to remove the $\mathrm{HCOO}^{-}$formed during electrooxidation of methanol. In general, the electrooxidation of small organic compounds on metal electrodes occur in the presence of reactive $\mathrm{M}(\mathrm{OH})_{\mathrm{ads}}$ species formed by hydroxyl adsorption on the electrode surfaces. Hence, the easily formed $\mathrm{Cu}-\mathrm{OH}_{\mathrm{ads}}$ (at lower potential when compared to $\mathrm{Pt}$ ) can readily oxidize the $\mathrm{Pt}-(\mathrm{HCOO})_{\mathrm{ads}}$ to $\mathrm{CO}_{2}$, which can increase the availability of active Pt sites for the adsorption and electrooxidation of methanol (as given below).

$$
\begin{aligned}
& \mathrm{Cu}+\mathrm{OH}^{-} \rightarrow \mathrm{Cu}-\mathrm{OH}_{\mathrm{ads}}+\mathrm{e}^{-} \stackrel{\mathrm{Pt}-(\mathrm{HCOO})_{\mathrm{ads}}}{\longrightarrow} \\
& \mathrm{Pt}+\mathrm{Cu}+\mathrm{H}_{2} \mathrm{O}+\mathrm{CO}_{2}+2 \mathrm{e}^{-} \\
& \mathrm{Cu}+\mathrm{OH}^{-} \rightarrow \mathrm{Cu}-\mathrm{OH}_{\mathrm{ads}}+\mathrm{e}_{\mathrm{ads}} \stackrel{\mathrm{Pt}-\mathrm{CO}_{\mathrm{ads}}}{\longrightarrow} \\
& \mathrm{Pt}+\mathrm{Cu}+\mathrm{CO}_{2}+2 \mathrm{e}^{-}
\end{aligned}
$$

The rate of reactions in accordance with the eqn (5) and (6) are higher than that of the reaction occurring in accordance with the eqn (2), which results enhanced catalytic activity in the presence of ' $\mathrm{Cu}$ ' nanoparticles on $\mathrm{Pt} / \mathrm{poly}(\mathrm{SDP} / \mathrm{CP} / \mathrm{BZ})-\mathrm{GO}$ catalyst.

(ii) Ethylene glycol oxidation. Ethylene glycol produces formic acid as a major intermediate along with other byproducts such as glyoxal, glycolic acid, glyoxylic acid and oxalic acid during the electrooxidation process. ${ }^{23}$
BZ)-GO catalyst could enhance the regeneration of poisoned platinum, which is more reactive towards intermediate products. ${ }^{24-27}$

Hence, the copper particles can increase the availability of more numbers of active Pt sites for the adsorption and electrooxidation of ethylene glycol. The rate of oxidation of the intermediate product proceeding through eqn (8) is always higher than that of the oxidation proceeding through the eqn (7), which might be due to the easy formation of $\mathrm{Cu}-\mathrm{OH}$ species at lower potential when compared to $\mathrm{Pt}-\mathrm{OH}$ species.

$$
\begin{aligned}
& \mathrm{Pt}+\mathrm{OH} \rightarrow \mathrm{Pt}-\mathrm{OH}_{\mathrm{ads}}+\mathrm{e}^{-} \stackrel{\mathrm{Pt}-\mathrm{HCOO}^{-}}{2 \mathrm{Pt}+\mathrm{CO}_{2}+\mathrm{H}_{2} \mathrm{O}+2 \mathrm{e}^{-}} \\
& \mathrm{Cu}+\mathrm{OH} \rightarrow \mathrm{Cu}-\mathrm{OH}_{\mathrm{ads}}+\mathrm{e}^{-} \stackrel{\mathrm{Pt}-\mathrm{HCOO}^{-}}{\mathrm{Cu}+\mathrm{Pt}}+\mathrm{CO}_{2}+\mathrm{H}_{2} \mathrm{O}
\end{aligned}
$$

The above results conclude that the $\mathrm{Pt}-\mathrm{Cu} / \mathrm{poly}(\mathrm{SDP} / \mathrm{CP} / \mathrm{BZ})-$ GO catalyst shows better catalytic activity through bi-functional effect than that of $\mathrm{Pt} /$ poly(SDP/CP/BZ)-GO catalyst. In addition to that Pt/poly(SDP/CP/BZ)-GO and Pt-Cu/poly(SDP/CP/BZ)-GO catalysts show better catalytic activity than that of the $\mathrm{Pt} / \mathrm{GO}$ and $\mathrm{Pt} /$ poly(SDP/CP/BZ) catalyst. So, poly(SDP/CP/BZ)-GO composite is a potent and good supporting material with enhanced activities for fuel cell applications.

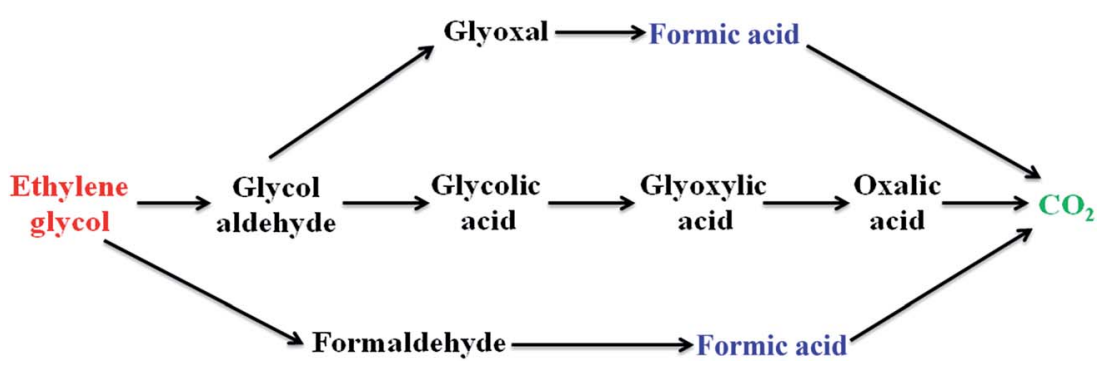

According to the above proposed mechanism, the major product formed during ethylene glycol oxidation is $\mathrm{HCOOH}$, which can be easily removed by the adding copper as second metal to $\mathrm{Pt} / \mathrm{poly}(\mathrm{SDP} / \mathrm{CP} / \mathrm{BZ})-\mathrm{GO}$ catalyst. The addition of copper could increase the catalytic activity by adsorbing the $\mathrm{OH}^{-}$ions in the electrolyte solution $(\mathrm{KOH})$ at lower potential comparable to that of platinum. Hence, copper as co-catalyst will help to remove the intermediate product like formic acid or CO or some other intermediates formed during electrooxidation of ethylene glycol.

In addition to that the electrooxidation small organic molecule/intermediates formed during the electrooxidation of alcohols on metal electrodes occurs in the presence of reactive $\mathrm{M}(\mathrm{OH})_{\text {ads }}$ species formed through hydroxyl group adsorption on the electrode surfaces. Hence, the formed $\mathrm{Cu}-\mathrm{OH}_{\text {ads }}$ can readily oxidize the $\mathrm{Pt}-(\mathrm{HCOO})_{\text {ads }}$ to $\mathrm{CO}_{2}$ compared to that of $\mathrm{Pt}-\mathrm{OH}_{\mathrm{ads}}$. In this regard, the copper nanoparticles in $\mathrm{Pt}-\mathrm{Cu} / \mathrm{poly}(\mathrm{SDP} / \mathrm{CP} /$
Overall, the oxidation current density of ethylene glycol is found to be higher than that of the oxidation current density of methanol, which may be the nature of byproduct formed during the electrooxidation of methanol. But, the ethylene glycol oxidation produces various intermediates such as glyoxal, glycolic acid, glyoxylic acid, oxalic acid and formic acid in alkaline solution (Fig. 7). Further, most of the $\mathrm{C}-\mathrm{C}$ bond cleavage in ethylene glycol takes place at higher potential, which will prevent the $\mathrm{CO}$ poisoning of platinum. However, the methanol cleavage mostly takes place at lower potential and hence the oxidation of 'CO' poison may not possible at a lower potential, which will decrease the active surface area that are essential for the adsorption and oxidation of methanol. Hence, the prepared catalysts show higher oxidation current density for ethylene glycol when compared to methanol.

3.3.2. CO stripping and chronoamperometric analysis. The CO tolerance of $\mathrm{Pt} / \mathrm{poly}(\mathrm{SDP} / \mathrm{CP} / \mathrm{BZ})-\mathrm{GO}$ and $\mathrm{Pt}-\mathrm{Cu} / \mathrm{poly}(\mathrm{SDP} /$ 

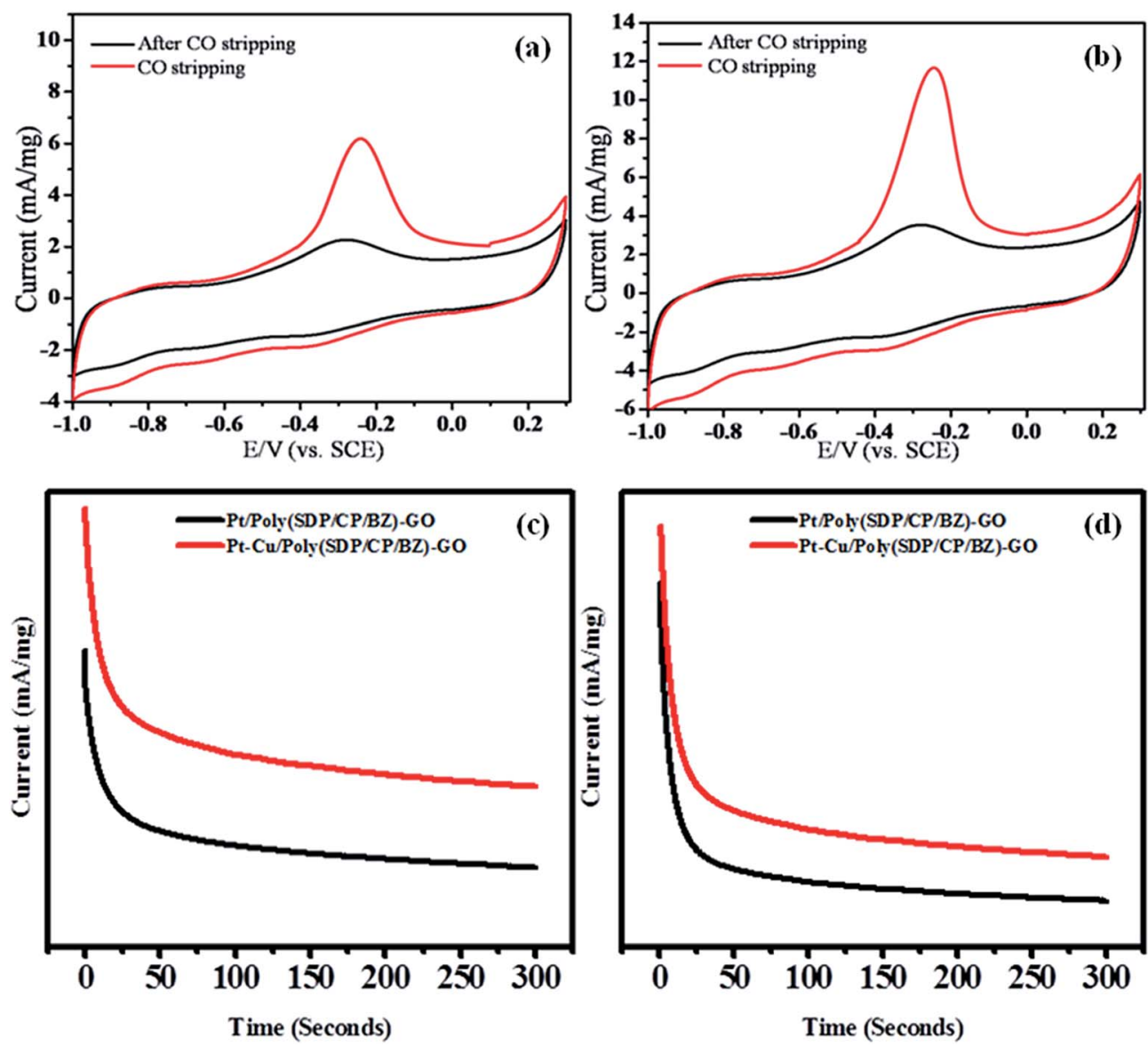

Fig. 5 CO stripping voltammograms for (a) Pt (b) Pt-Cu decorated poly(SDP/CP/BZ)-GO catalysts in $0.5 \mathrm{M}$ KOH solution at a scan rate $50 \mathrm{mV}$ $\mathrm{s}^{-1}$ and chronoamperograms of $\mathrm{Pt}$ and $\mathrm{Pt}-\mathrm{Cu}$ decorated poly(SDP/CP/BZ) $-\mathrm{GO}$ catalysts in (c) $0.5 \mathrm{M} \mathrm{KOH}+0.5 \mathrm{M} \mathrm{methanol} \mathrm{and} \mathrm{(d)} 0.5 \mathrm{M} \mathrm{KOH}+$ $0.5 \mathrm{M}$ ethylene glycol.

$\mathrm{CP} / \mathrm{BZ}$ )-GO catalysts were determined by $\mathrm{CO}_{\text {ads }}$ striping analysis (Fig. 5(a and b)). Pt-Cu/poly(SDP/CP/BZ)-GO catalyst shows lower onset potential and peak potentials for carbon monoxide oxidation than that of the Pt/poly(SDP/CP/BZ)-GO catalyst. The onset electrode potential is negatively shifted by $23 \mathrm{mV}$, which indicating that the doping of copper as co-metal on Pt/poly(SDP/ $\mathrm{CP} / \mathrm{BZ}$ )-GO catalyst can significantly improve the $\mathrm{CO}$ resistance or oxidation. Therefore, the CO stripping results authenticate the stability and reduced poisonous effect of $\mathrm{Pt}-\mathrm{Cu} / \mathrm{poly}(\mathrm{SDP} /$ CP/BZ)-GO catalyst.

The stability with respect to time and reproducibility related to activities of $\mathrm{Pt} /$ poly(SDP/CP/BZ)-GO and $\mathrm{Pt}-\mathrm{Cu} /$ poly(SDP/CP/ BZ)-GO catalysts in methanol and ethylene glycol oxidation were determined by chronoamperometry analysis. The chronoamperometry analysis results of $\mathrm{Pt} / \mathrm{poly}(\mathrm{SDP} / \mathrm{CP} / \mathrm{BZ})-\mathrm{GO}$ and $\mathrm{Pt}-\mathrm{Cu} / \mathrm{poly}(\mathrm{SDP} / \mathrm{CP} / \mathrm{BZ})-\mathrm{GO}$ catalysts in $0.5 \mathrm{M} \mathrm{KOH}+0.5 \mathrm{M}$ methanol and $0.5 \mathrm{M} \mathrm{KOH}+0.5 \mathrm{M}$ ethylene glycol solutions were shown in Fig. 5(c and d). The current density decreases rapidly for both the catalysts at the initial stage, which may be due to the formation of the intermediate carbonaceous species during methanol and ethylene glycol oxidation reaction. ${ }^{28}$ The steady state current observed for the as prepared catalysts clearly confirms the relative stability, reproducibility and higher catalytic activity of $\mathrm{Pt}-\mathrm{Cu} /$ poly(SDP/CP/BZ)-GO catalyst.

From the overall electrooxidation analysis, it was observed that the $\mathrm{Pt}-\mathrm{Cu} /$ poly $(\mathrm{SDP} / \mathrm{CP} / \mathrm{BZ})-\mathrm{GO}$ catalyst exhibits higher catalytic activity when compared to $\mathrm{Pt}-\mathrm{Cu} /$ poly(SDP/CP/BZ)-GO. So, it has been nominated as the electrode material for the construction of single stack test fuel cell for its power generation performance.

3.3.3. HPLC analysis. High performance liquid chromatography (HPLC) analyses were carried out to predict the intermediate products obtained during the ethylene glycol and glycerol oxidation on $\mathrm{Pt}$, and $\mathrm{Pt}-\mathrm{Cu}$ deposited poly(SDP/CP/BZ)GO composite. The HPLC analysis confirms that $\mathrm{Pt}$ and $\mathrm{Pt}-\mathrm{Cu}$ nanoparticles present on poly(SDP/CP/BZ)-GO are able to oxidize the ethylene glycol into single carbon fragments at a high percentage under mild experimental conditions. The chromatograms obtained from HPLC analysis during the electrooxidation of ethylene glycol on $\mathrm{Pt}$ and $\mathrm{Pt}-\mathrm{Cu}$ deposited poly(SDP/CP/BZ)-GO composite was shown in Fig. 6.

The Fig. 6 shows five intermediate peaks, which are corresponding to glyoxal, oxalic acid, glyoxylic acid, glycolic acid and formic acid formed during ethylene glycol oxidation. At first, the ethylene glycol oxidized to give five intermediates such as 

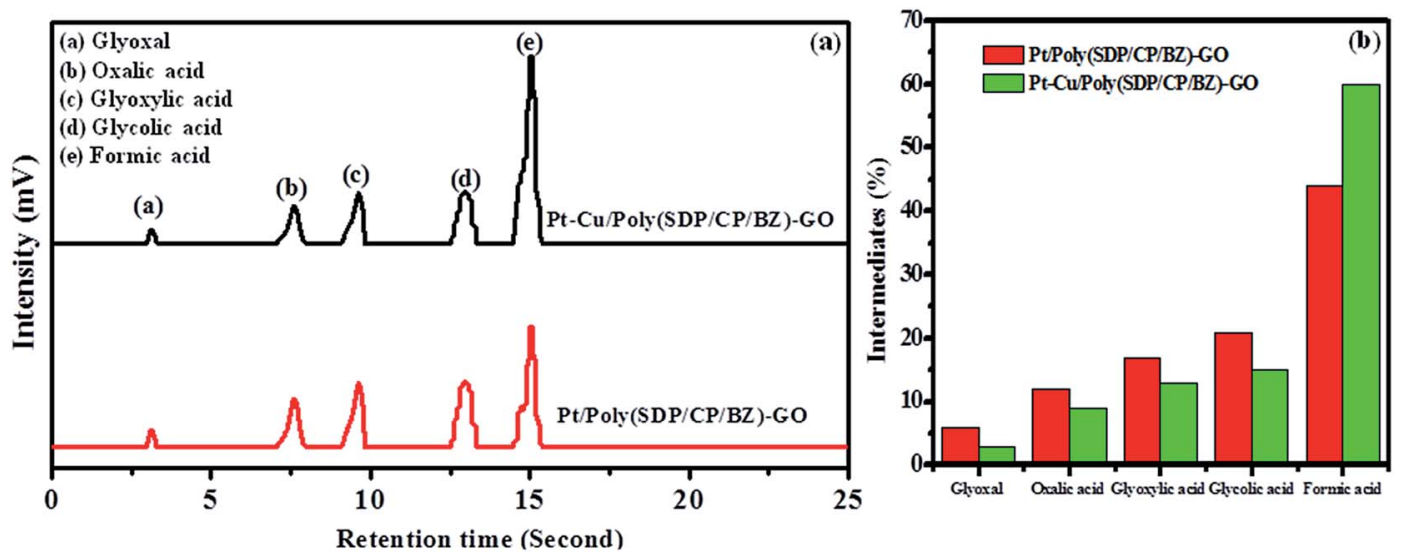

Fig. 6 (a) Chromatograms obtained from HPLC analysis and (b) comparative bar graph of intermediates produced during the electrooxidation of ethylene glycol on Pt/poly(SDP/CP/BZ)-GO and Pt-Cu/poly(SDP/CP/BZ)-GO catalysts.

glyoxal, oxalic acid, glyoxylic acid, glycolic acid and formic acid. The intermediates like glyoxal, oxalic acid, glyoxylic acid and glycolic acid are further oxidized and they undergo cleavage of $\mathrm{C}-\mathrm{C}$ bond to produce $\mathrm{CO}_{2}$. In the same way, the formic acid oxidized to give $\mathrm{CO}_{2}$. Hence, the above discussion gives clear information regarding the intermediate products formed during the ethylene glycol oxidation.
3.3.4. Fabrication of single stack test cell using Pt-Cu/ poly(SDP/CP/BZ)-GO catalyst as electrode material. Initially, the single stack direct alcohol alkaline fuel cell performances were checked with respect to different temperature and concentration of the fuels using $\mathrm{Pt}-\mathrm{Cu} / \mathrm{poly}(\mathrm{SDP} / \mathrm{CP} / \mathrm{BZ})-\mathrm{GO}$ as electrode material. For this, the $\mathrm{Pt}-\mathrm{Cu} / \mathrm{poly}(\mathrm{SDP} / \mathrm{CP} / \mathrm{BZ})-\mathrm{GO}$ catalyst

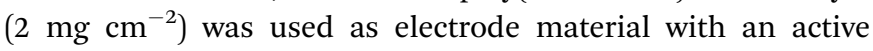
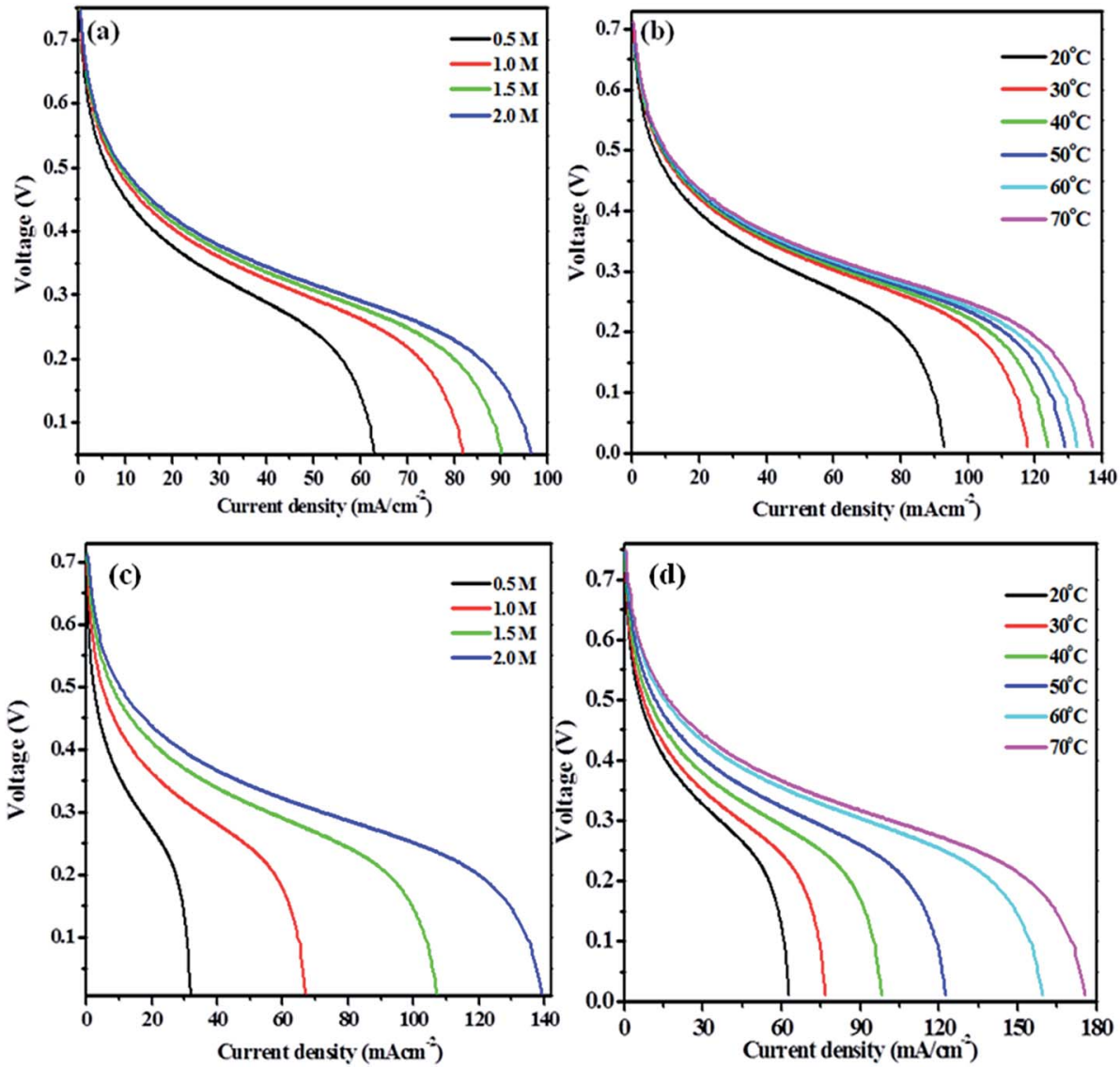

Fig. 7 Current density with respect to different (a) concentration of methanol and (b) temperature (c) concentration of ethylene glycol and (d) temperature on $\mathrm{Pt}-\mathrm{Cu} /$ poly(SDP/CP/BZ)-GO electrode in single stack test cell. 
surface area of $2.5 \times 2.5 \mathrm{~cm}^{2}$. The methanol ethylene glycol fuels were pumped with a flow rate of $2.0 \mathrm{~mL} \mathrm{~min}{ }^{-1}$ into the anode side and the pure oxygen gas was passed on the cathode side at a flow rate of $100 \mathrm{~cm}^{3} \mathrm{~min}^{-1}$. Fig. 7(a-d) show the cell polarization curves of methanol and ethylene glycol obtained by plotting the current densities against the potential for $\mathrm{Pt}-\mathrm{Cu}$ / poly(SDP/CP/BZ)-GO electrode in single direct alkaline alcohol fuel cells at different concentrations and temperatures. From the single stack fuel cell test results, it was clearly noticed that the current densities of the cell were increased with increasing the concentration of the fuels and the temperature of the cell. Further, it was observed that the current density and open circuit potential were increased with respect to increases in the temperature.

For methanol fuel, the current density increases with increasing the methanol concentration up to $4.5 \mathrm{M}$ methanol solution in $1 \mathrm{M} \mathrm{KOH}$ solutions and further increase in the concentration of fuel shows no significant changes in the current densities. So, the maximum current density noticed for methanol solution was $97 \mathrm{~mA} \mathrm{~cm}^{-2}$ (Fig. 7(a)). The large increase in the current densities was noticed up to $2.0 \mathrm{M}$ methanol solution, which may be taken as an optimum concentration of methanol. Hence, the effect of temperature in $2.0 \mathrm{M}$ methanol $+1.0 \mathrm{M} \mathrm{KOH}$ solution is carried out at different temperature ranging from 20 , 30, 40, 50, 60, 70 and $80{ }^{\circ} \mathrm{C}$ (Fig. 7(b)). The effect of temperature results concludes that the maximum current density obtained is $137 \mathrm{~mA} \mathrm{~cm}^{-2}$ at $70{ }^{\circ} \mathrm{C}$.

For ethylene glycol fuel, the current density increases up to 2.5 $\mathrm{M}$ ethylene glycol in $1.0 \mathrm{M} \mathrm{KOH}$ solution. However, the significant increase in current density was noticed upto $2.0 \mathrm{M}$ though an increase in current density was observed upto $2.5 \mathrm{M}$ ethylene glycol. So, the optimum concentration of the ethylene glycol is taken as $2.0 \mathrm{M}$ in $1.0 \mathrm{M} \mathrm{KOH}$ solution since the uniform or significant increase in the current density is observed up to 2.0 M (Fig. 7(c)). The current density was increased up to $80^{\circ} \mathrm{C}$, though the current density is increased dramatically at $70{ }^{\circ} \mathrm{C}$ (Fig. $7(\mathrm{~d})$ ). So, the optimum temperature is taken as $70{ }^{\circ} \mathrm{C}$ for

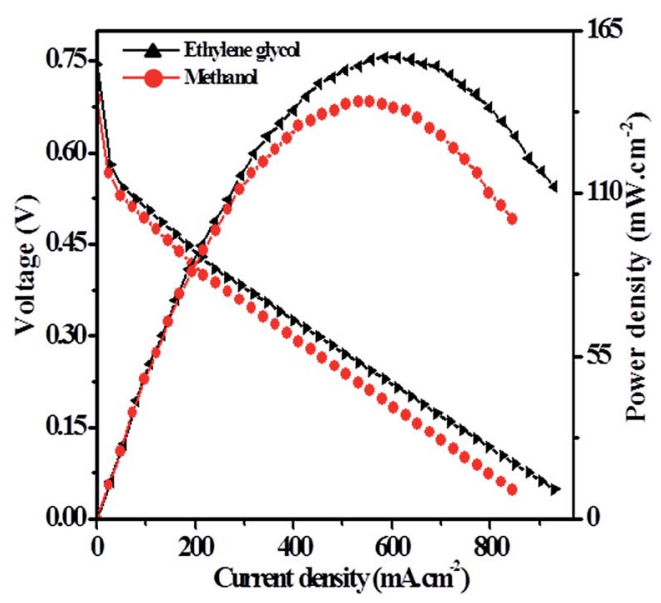

Fig. 8 Polarization and current density curves of single stack fuel cell using $\mathrm{Pt}-\mathrm{Cu} /$ poly(SDP/CP/BZ)-GO as electrode material in $2.0 \mathrm{M}$ methanol and 2.0 M ethylene glycol in $1.0 \mathrm{M} \mathrm{KOH}$ solution at $70{ }^{\circ} \mathrm{C}$.
$\mathrm{Pt}-\mathrm{Cu} / \mathrm{poly}(\mathrm{SDP} / \mathrm{CP} / \mathrm{BZ})-\mathrm{GO}$ electrode for ethylene glycol $(2.0 \mathrm{M})$ in $1.0 \mathrm{M} \mathrm{KOH}$ solution.

Hence, the direct alkaline alcohol test fuel cell is compared using the concentration of $2.0 \mathrm{M}$ alcohol fuels in $1.0 \mathrm{M} \mathrm{KOH}$ solution at a constant temperature of $70{ }^{\circ} \mathrm{C}$ on $\mathrm{Pt}-\mathrm{Cu} / \mathrm{poly}(\mathrm{SDP} /$ $\mathrm{CP} / \mathrm{BZ}$ )-GO catalyst as electrode material. The performance of $\mathrm{Pt}-\mathrm{Cu} /$ poly(SDP/CP/BZ)-GO electrode in single stack fuel cell with respect to the current density, power density and voltage relationship under optimum temperature $\left(70{ }^{\circ} \mathrm{C}\right)$ and alcohol concentration (2.0 M) were shown in Fig. 8. From the Fig. 8, the maximum power densities of 112.24 and $140.67 \mathrm{~mW} \mathrm{~cm}^{-2}$ were noticed for methanol and ethylene glycol fuels, respectively. Further, the observed power density of the $\mathrm{Pt}-\mathrm{Cu} /$ poly $(\mathrm{SDP} / \mathrm{CP} /$ $\mathrm{BZ}-\mathrm{GO}$ catalysts are found to be higher than that of the literature data. ${ }^{29-53}$ From the overall studies, it was concluded that the prepared $\mathrm{Pt}-\mathrm{Cu} /$ poly $(\mathrm{SDP} / \mathrm{CP} / \mathrm{BZ})-\mathrm{GO}$ catalyst is a potent electrode for direct alkaline alcohol fuel cells.

\section{Conclusion}

In the present investigation, poly(SDP/CP/BZ)-GO composite as supporting material was prepared for the electrooxidation of methanol and ethylene glycol in favor of fuel cell applications. For this application, platinum and platinum-copper nanoparticles were loaded on the novel poly(SDP/CP/BZ)-GO composite material. The resulted catalysts were subjected to electrooxidation of alcohols and CO tolerance studies to confirm their performance for fuel cell applications. The bimetallic $\mathrm{Pt}-\mathrm{Cu}$ nanoparticles loaded poly(SDP/CP/BZ)-GO exhibits good $\mathrm{CO}$ tolerance and higher electrocatalytic activities of alcohols than that of platinum loaded poly(SDP/CP/BZ)-GO composite. Hence, the better performed novel $\mathrm{Pt}-\mathrm{Cu} /$ poly(SDP/ $\mathrm{CP} / \mathrm{BZ}$ )-GO material was used for fuel cell construction. The single stack direct alkaline alcohol test fuel cell with an active surface area of $6.25 \mathrm{~cm}^{2}$ shows the maximum power density of 112.24 and $140.67 \mathrm{~mW} \mathrm{~cm}{ }^{-2}$ for methanol and ethylene glycol fuels, respectively.

\section{Acknowledgements}

The authors like to thank DST/Nanomission, New Delhi, India for the financial support to carry out this work and the establishment of Nanotech Research Lab through the grant No. SR/ NM/NS-05/2011(G).

\section{References}

$1 \mathrm{H}$. Vaghari, H. Jafarizadeh-Malmiri, A. Berenjian and N. Anarjan, Sustainable Chem. Processes, 2013, 1, 16.

2 E. Antolini and E. R. Gonzalez, J. Power Sources, 2010, 195, 3431-3450.

3 K. Matsuoka, Y. Iriyama, T. Abe, M. Matsuoka and Z. Ogumi, J. Power Sources, 2005, 150, 27-31.

4 H. A. Miller, F. Vizza and A. Lavacchi, Nanostruct. Sci. Technol., 2016, 477-516.

5 K. I. Ozoemena, $R S C A d v .$, 2016, 6, 89523-89550. 
6 M. Ando, T. Kobayashi, S. Iijima and M. Haruta, J. Mater. Chem., 1997, 7, 1779-1783.

7 L. Pan, H. Zhao, W. Shen, X. Dong and J. Xu, J. Mater. Chem. A, 2013, 1, 7159.

8 S. Park, S. J. Park and S. Kim, Bull. Korean Chem. Soc., 2012, 33, 4247-4250.

9 M. M. Shahid, A. Pandikumar, A. M. Golsheikh, N. M. Huang and H. N. Lim, RSC Adv., 2014, 4, 62793-62801.

10 A. A. Navaee and A. Salimi, Electrochim. Acta, 2016, 211, 322330.

11 Y. H. Kwok, A. C. H. Tsang, Y. Wang and D. Y. C. Leung, J. Power Sources, 2017, 349, 75-83.

12 D. Dong Liu, L. Li and T. You, J. Colloid Interface Sci., 2017, 487, 330-335.

13 K. Kakaei, Electrochim. Acta, 2015, 165, 330-337.

14 H. Ashassi-Sorkhabi, B. R. Moghadam, E. Asghari, R. Bagheri and R. Kabiri, J. Taiwan Inst. Chem. Eng., 2016, 69, 118-130.

15 Z. Bai, L. Niu, Q. Zhang, H. Feng, L. Yang, Z. Yang and Z. Chen, Int. J. Hydrogen Energy, 2015, 40, 14305-14313.

16 C.-S. Liu, X.-C. Liu, G.-C. Wang, Ru-P. Liang and J.-D. Qiu, J. Electroanal. Chem., 2014, 728, 41-50.

17 H. R. Allcock, J. Mater. Chem., 1994, 6, 1476-1491.

18 Z. Q. Yao, M. S. Zhu, F. X. Jiang, Y. K. Du, C. Y. Wang and P. Yang, J. Mater. Chem., 2012, 22, 13707-13713.

19 D. Li, M. B. Muller, S. Gilje, R. B. Kaner and G. Wallace, Nat. Nanotechnol., 2008, 3, 101-105.

20 W. H. Zhang, G. Zhang and X. Y. Wei, Appl. Catal., A, 2016, 509, 111-117.

21 F. Tuinstra and J. L. Koenig, J. Chem. Phys., 1970, 53, 1126.

22 D. Graf, F. Molitor, K. Ensslin, C. Stampfer, A. Jungen, C. Hierold and L. Wirtz, Nano Lett., 2007, 7, 238.

23 H. J. Kim, S. M. Choi, S. Green, G. A. Tompsett, S. H. Lee, G. W. Huber and W. B. Kim, Appl. Catal., B, 2011, 101, 366-375.

24 B. Beden, F. Kadirgan, C. Lamy and J. M. Leger, J. Electroanal. Chem., 1982, 142, 171-190.

25 J. Prabhuram and R. Manoharan, J. Power Sources, 1998, 74, 54-61.

26 A. V. Tripkovi, K. Dj. Popović, J. D. Momčilović and D. M. Draić, J. Electroanal. Chem., 1996, 418, 9-20.

27 X.-Z. Fu, Y. Liang, S.-P. Chen, J.-D. Lin and D.-W. Liao, Catal. Commun., 2009, 10, 1893-1897.

28 R. T. S. Oliveira, M. C. Santos, P. A. P. Nascente, L. O. S. Bulhões and E. C. Pereira, Int. J. Electrochem. Sci., 2008, 3, 970-979.

29 Y. Fang, T. Wang, R. Miao, L. Tang and X. Wang, Electrochim. Acta, 2010, 55, 2404-2408.

30 Y. C. Park, S. H. Lee, S. K. Kim, S. Lim, D. H. Jung, D. Y. Lee, S. Y. Choi, H. Ji and D. H. Peck, Int. J. Hydrogen Energy, 2010, 35, 4320-4328.
31 C. C. Yang, W. C. Chien and Y. J. Li, J. Power Sources, 2010, 195, 3407-3415.

32 C. C. Yang, S. J. Chiu, W. C. Chien and S. S. Chiu, J. Power Sources, 2010, 195, 2212-2219.

33 C. Xu, A. Faghri, X. Li and T. Ward, Int. J. Hydrogen Energy, 2010, 35, 1769-1777.

34 L. Feng, J. Zhang, W. Cai, L. Liang, W. Xing and C. Liu, J. Power Sources, 2011, 196, 2750-2753.

35 Y. J. Chiu, T. L. Yu and Y. C. Chung, J. Power Sources, 2011, 196, 5053-5063.

36 A. H. Haghighi, M. M. Hasani-Sadrabadi, E. Dashtimoghadam, Gh. Bahlakeh, S. E. Shakeri, F. S. Majedi, S. H. Emami and H. Moaddel, Int. J. Hydrogen Energy, 2011, 36, 3688-3696.

37 J. C. Tsai and C. K. Lin, J. Power Sources, 2011, 196, 93089316.

38 F. Lufrano, V. Baglio, O. Di Blasi, P. Staiti, V. Antonucci and A. S. Aricò, Phys. Chem. Chem. Phys., 2012, 14, 2718-2726.

39 J. Y. Park, Y. Seo, S. Kang, D. You, H. Cho and Y. Na, Int. J. Hydrogen Energy, 2012, 37, 5946-5957.

40 R. Padmavathi, R. Karthikumar and D. Sangeetha, Electrochim. Acta, 2012, 71, 283-293.

41 T. Zhou, J. Zhang, J. Qiao, L. Liu, G. Jiang, J. Zhang and Y. Liu, J. Power Sources, 2013, 227, 291-299.

42 Y.-S. Ye, M.-Y. Cheng, X.-L. Xie, J. Rick, Y.-J. Huang and F.-C. Chang, J. Power Sources, 2013, 239, 424-432.

43 J.-F. Wu, C.-F. Lo, L.-Y. Li, H.-Y. Li, C.-M. Chang, K.-S. Liao, C.-C. Hu, Y.-L. Liu and S. J. Lue, J. Power Sources, 2014, 246, 39-48.

44 X. Yan, S. Gu, G. He, X. Wu and J. Benziger, J. Power Sources, 2014, 250, 90-97.

45 I. Kruusenberg, S. Ratso, M. Vikkisk, P. Kanninen, T. Kallio, A. M. Kannan and K. Tammeveski, J. Power Sources, 2015, 281, 94-102.

46 Y. Li, C. Liu, Y. Liu, B. Feng, L. Li, H. Pan, W. Kellogg, D. Higgins and G. Wu, J. Power Sources, 2015, 286, 354-361.

47 L. Demarconnay, S. Brimaud, C. Coutanceau and J. M. Léger, J. Electroanal. Chem., 2007, 601, 169-180.

48 A. Marchionni, M. Bevilacqua, C. Bianchini, Y. X. Chen, J. Filippi, P. Fornasiero, A. Lavacchi, H. Miller, L. Q. Wang and F. Vizza, ChemSusChem, 2013, 6, 518-528.

49 L. Xin, Z. Y. Zhang, J. Qi, D. Chadderdon and W. Z. Li, Appl. Catal., B, 2012, 125, 85-94.

50 K. Matsuoka, Y. Iriyama, T. Abe, M. Matsuoka and Z. Ogumi, J. Power Sources, 2005, 150, 27-31.

51 L. An, L. Zeng and T. S. Zhao, Int. J. Hydrogen Energy, 2013, 38, 10602-10606.

52 J. R. Varcoe, R. C. T. Slade, E. L. H. Yee, S. D. Poynton and D. J. Driscoll, J. Power Sources, 2007, 173, 194-199.

53 F. Munoz, C. Hua, T. Kwong, L. Tran, T. Q. Nguyen and J. L. Haan, Appl. Catal., B, 2015, 174-175, 323-328. 